\title{
ROLE OF STREPTOCOCCAL INFECTION IN THE ACUTE PATHOLOGY OF LYMPHATIC FILARIASIS
}

\author{
ESTERRE P.*, PLICHART C.*, HUIN-BLONDEY M.O.** \& NGUYEN L.**
}

\begin{abstract}
Summary :
Growing evidence suggest that secondary bacterial, mainly streptococcal, infections contribute significantly to recurrent episodes of acute adenolymphangitis (ADL) of filarial origin. We examined the role of group A streptococci in the progression of lymphedema in Polynesian patients with filariasis-related ADL (22 cases) or chronic pathology (10 cases), or with erysipela (10 patients) and, as controls, in 20 healthy adults. Antistreptolysin $O$ (ASLO) and anti-streptodornase B (ASDB) titers were systematically determined in parallel to parasitological and biochemical tests. ASLO and ASDB assays were positive in $100 \%$ of erysipela, $75 \%$ of filarial ADL as compared to $50 \%$ of chronic pathology and $39 \%$ of healthy controls. Interestingly, by opposition to ASLO titers which were not significantly different between the four groups, ASDB titers were higher in $A D L$ $(p=0.019)$ and erysipela $(p=0.002)$ than in controls. These results support the hypothesis that recurrent streptococcal infections may have an important role in the pathogenesis of $A D L$ in lymphatic filariasis.
\end{abstract}

KEY WORDS : lymphatic filariasis, Wuchereria bancrofti, group A streptococci, acute adenolymphangitis, French Polynesia.

MOTS CLÉS : filariose lymphatique, Wuchereria bancroffi, streptocoques du groupe $A$, adénolymphangite aigüe, Polynésie Française.

$\mathrm{H}$ uman lymphatic filariasis is caused by lymphatic-dwelling parasites, mainly the species Wuchereria bancrofti (more than $90 \%$ of indexed cases), and is characterized by a wide range of clinical manifestations affecting the limbs, genitals, breasts and other parts of the body (Partono, 1987). Acute and chronic disease manifestations result in a worldwide annual morbidity estimated to reach four million disably-ajusted life years, making this disease as the second leading cause of disability to mankind (Bradley, 1997). In order to interrupt the transmission by vectors, and doing so trying to prevent disease,

\footnotetext{
* Immunology Unit and

** Clinical Research Unit,

Institut Territorial de Recherches Médicales Louis Malardé, BP 30, Papeete, 98713 Tahiti (French Polynesia).

Correspondence: Dr Philippe Esterre, Head of Immunology Unit, Institut Territorial de Recherches Médicales Louis Malardé, BP 30, Papeete, 98713 Tahiti (Polynésie Française).

Fax: 689431590 - E-mail: esterre@malarde.pf
}

Résumé : RÔLE DES INFECTIONS STREPTOCOCCIQUES DANS LA PATHOLOGIE AIGUË D'ORIGINE FILARIENNE

Les évidences s'accumulent quant à un rôle important des infections bactériennes secondaires, notamment d'origine streptococcique, dans la pathogénèse des adénolymphangites $(A D L)$ aiguës d'origine filarienne. Nous avons recherché l'intervention de streptocoques du groupe A dans la progression des lymphoedèmes de malades, d'origine polynésienne, présentant une $\mathrm{ADL}(22$ patients) ou une pathologie chronique (10 cas) d'origine filarienne, un érysipèle 110 patients) et, à titre de contrôle, 20 adultes sains. Des épreuves sérologiques de détermination des anticorps anti-streptolysine $\bigcirc(\mathrm{ASLO}$ ) ou antistreptodornase $B(A S D B)$ ont été pratiquées, en parallèle aux investigations parasitologiques et biochimiques classiques. Les tests ASLO et ASDB se sont révélés positifs pour $100 \%$ des érysipèles, $75 \%$ des ADL filariennes et encore $50 \%$ des filariens à pathologie chronique et $39 \%$ des contrôles sains. Si les titres en ASLO ne sont pas significativement différents entres ces quatre groupes analysés, il est intéressant de noter que les titres en ASDB sont statistiquement plus élevés, pour les ADL filariennes $(p=0,019)$ et les erysipèles $(p=0,002)$, que la normale. Ces résultats semblent confirmer l'hypothèse selon laquelle des infections streptococciques récurrentes, fréquentes en zone tropicale humide comme la Polynésie, jouent un rôle important dans la pathogénèse des $A D L$ associées à la filariose lymphatique. national control programs have been implemented. But even when transmission is eliminated, chronic and acute symptoms can continue to be important public health problem (Fan et al., 1995).

The acute form of bancroftian filariasis involves lymphadenitis and lymphangitis, generally called adenolymphangitis (ADL) and is supposed to be, at least partly, a local immunological response to adult worms associated to mechanical damages of the lymphatic vessels made by these motile parasites. Repeated lymphatic damages related to adult worms activity is supposed to result in increased susceptibility to secondary bacterial infections, leading to progression of lymphoedema and elephantiasis (Olszewski et al., 1993, 1994; Schacher \& Sahyoun, 1967; Shenoy et al., 1995). The relative contribution of these immunological, parasitological and bacterial components is poorly defined. Based on serological results, streptococcal infection have been recently considered as a precipitating factor of ADL in Brugia malayi- (Suma et al., 1997) and 
W. bancrofti- (Vincent et al., 1998) associated morbidity. The present study examined serologically infections with group $\mathrm{A} \beta$ hemolytic streptococci, one of the main common pathogenic bacteria in tropical areas with a marked affinity for the lymphatics, in ADL of filarial and bacterial (erysipela, see clinical definition in Chartier \& Grosshans, 1990, and Vincent et al., 1998) origins, compared to controls with the same ethnological and social conditions.

\section{MATERIAL AND METHODS}

\section{SERUM SAMPLES}

$\mathrm{P}$ rospective patients, examined by an experienced medical staff (Clinical Research Unit, Institut Malardé, Papeete, French Polynesia), were carefully questioned for a clinical history of recurrent episodes of ADL (Suma et al., 1997; Vincent et al., 1998). The selected population consisted of 22 patients with filarial ADL, 10 patients with chronic pathology (six hydroceles, two elephantiasis and two chyluria) and 10 with typical erysipelas and 20 endemic healthy controls of the same ethnological (Polynesian) and social (life-long residents of Tahiti island, Society archipelago) conditions. After informed consent, diligent clinical and laboratory investigations (complete hemogram, serum biochemistry and detection of microfilariae by Nucleopore ${ }^{\circledR}$ membrane filtration) were carried in all the subjects enrolled in the study. The 20 healthy adults, negative for the specific criteria, were carefully examined for skin or lymphatic diseases which could interfere with the present study.

\section{METHODS}

In addition to the previously cited laboratory investigations, detection of filaria-specific immunoglobulins (IgG) was mesured by ELISA using a soluble antigen extract from $B$. malayi worm and antigenemia (Chanteau et al., 1994; Nicolas et al., 1997; Ottesen et al., 1997) were tested with a quick immunochromatographic test (ICT Filariasis ${ }^{\circledR}$, ICT Diagnostics Ltd, Brookvale, Australia) recently validated. In case of positive results with the ICT assay, a reference ELISA-based technique (Og4c3 kit, JCU Tropical Biotech Ltd., Townsville, Australia) was used for confirmation (Nguyen et al., 1999). We also studied the antistreptococcal antibody responses by estimating the anti-streptolysin O (ASLO) titers with an immunoturbidimetric assay (Tina-Quant ${ }^{\circledR}$ ASLO, using an Hitachi 717 instrument, BoehringerMannheim, Mannheim, Germany), and the anti-streptodornase B (ASDB) with an enzymatic inhibition (ADNase $\mathrm{B}^{\circledR}$, Dade Behring, Paris La Défense, France). When using both ASLO and ASDB tests, nearly all group A streptococcal infections can be detected
(Ayoub, 1991). In ten patients studied two or three times during the one-year follow-up period, the elevated titers were persistent (data not shown). Given a suggestive clinical history of recurrent ADL, elevation of either the ASLO or ASDB titers is considered as evidence of an antecedent streptococcal infection (Ayoub, 1991; Vincent et al., 1998). ASLO titers are considering to rise about one week after the initial infection, with a maximum after three to five weeks, and to return to normal in six to 12 months, except in case of reinfection by streptococci (Chartier \& Grosshans 1990; Suma et al., 1997). Thus ASLO are considered to represent a marker of recent streptococcal infection. ASDB response seem to be more stable than ASLO reponse, independantly of the demonstration of a specific site of streptococcus infection, and reach its maximum after only six to nine weeks with a slower return to normal levels (Kaplan et al., 1970; Vincent et al., 1998): thus they represent an indicator of more chronic streptococcal infection.

\section{STATISTICAL ANALYSIS}

ASLO and ASDB titers were indifferently used as such or transformed to 10-based log before applying $t$-tests for independant samples. $P$ values lower than 0.05 were considered significant. We used statistical analysis softwares (Stamed, Medical Computer lab., Faculty of Medicine, Nancy, France and Statistica 5, StatSoft, Tulsa, USA) for performing the calculations.

\section{RESULTS}

\section{CLINICAL PRESENTATION AND FILARIA-SPECIFIC IGG}

1 The group of 22 patients with filariasis-related ADL were examined on the occasion of an acute attack of lymphangitis with edema, but none of them showed a site of entry for bacteria. Most of them $(95.5 \%)$ were amicrofilaremic with no antigenemia (91\%), and specific IgG were only detected in $41 \%$ of this sample. The second group of patients had chronic lymphatic filariasis pathology (six hydroceles, two elephantiasis and two recurrent chyluria) without any ADL episode during the previous year. Except the two cases of chyluria, all patients were negative for microfilaremia and antigenemia, these last result being confirmed by an ELISA reference assay. Specific IgG were identified in $50 \%$ of the sample, including the two chyluria. The 10 patients with a typical acute erysipela (Vincent et al., 1998), most of them with irreversible edema and skin thickening, wera all negative for microfilaremia, antigenemia and, except one (at the lower limit of positivity), for filaria specific IgG. 


\begin{tabular}{lcccc}
\hline & \multicolumn{4}{c}{$\begin{array}{c}\text { Anti- } \\
\text { genemia } \\
\text { (ITC }\end{array}$} \\
& $\begin{array}{c}\text { Microfilar. } \\
\text { prevalence } \\
\text { (\%) }\end{array}$ & $\begin{array}{c}\text { card test) } \\
\text { (\%) }\end{array}$ & $\begin{array}{c}\text { ASLO } \\
\text { (UI/ml) }\end{array}$ & $\begin{array}{c}\text { ASDB } \\
\text { titers }\end{array}$ \\
\hline $\begin{array}{l}\text { Erysipelas } \\
(\mathrm{n}=10)\end{array}$ & 0.0 & 0.0 & $193.2 \pm 75.7$ & $693.6 \pm 535.9$ \\
$\begin{array}{l}\text { ADL } \\
(\mathrm{n}=22)\end{array}$ & 4.5 & 9.0 & $223.3 \pm 164.9$ & $807.0 \pm 879.7$ \\
$\begin{array}{l}\text { Chronic. Pathol. } \\
(\mathrm{n}=10)\end{array}$ & $20^{*}$ & $20^{*}$ & $335.6 \pm 405.9$ & $402.1 \pm 532.0$ \\
$\begin{array}{l}\text { Controls } \\
(\mathrm{n}=20)\end{array}$ & 0.0 & 0.0 & $212.5 \pm 101.3$ & $249.0 \pm 148.5$ \\
\hline
\end{tabular}

The two cases of chyluria were both microfilaremic and positive with ELISA- and ICT-based detection assays for circulating worm antigens

Table I. - Laboratory results of the detection of microfilaria, antigenemia and antistreptococcal antibodies in erysipelas, Wuchereria bancrofti-associated adenolymphangitis (ADL) or chronic pathology and healthy controls, from French Polynesia.

\section{ANTISTREPTOCOCCAL ANTIBODY RESPONSES}

ASLO and/or ASDB antibodies were positive in $100 \%$ of erysipela ( $p=0.001$, by comparison with controls), $75 \%$ of of filarial ADL ( $p=0.04), 50 \%$ of chronic pathology ( $p>0.05$, but not with the two chyluria), and $39 \%$ of healthy controls (Table I). The ASLO titers were not significantly different between the four groups, but ASDB titers were higher in erysipela $(p=0.002)$ and ADL $(p=0.019)$, but not in patients with chronic patho$\operatorname{logy}(p>0.05)$, than in controls.

\section{DISCUSSION}

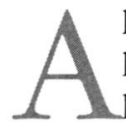
large proportion of residents affected by acute lymphatic filariasis involves group A $\beta$ hemolytic streptococci. About $75 \%$ of the studied sample with filarial ADL has positive levels of ASLO and/or ASDB antibodies, a result to be compared to the $50 \%$ and $90 \%$ percentages observed in a bancroftian (Vincent et al., 1998) and a brugian (Suma et al., 1997) lymphatic filariasis focus, respectively. These results, and previous bacteriological investigations (Olszewski et al., 1994; Shenoy et al., 1995), convincingly demonstrate that streptococci have a significant role, even if not exclusive, in the pathology of acute ADL associated to lymphatic filariasis. In addition, half of the patients with chronic pathology (but interestingly not with chyluria) have also antistreptococcal antibodies. This confirms the propensity of streptococci for invading poorly vascularized tissues, as previoulsy noted for elephantiasis (Nutman \& Weller, 1994). It is noted that $39 \%$ of healthy residents of Tahiti island, as compared to $24 \%$ in the Dominican republic (Vincent et al., 1998), have past or present streptococcal infections always ignored (or neglected) on a clinical point of view. This last result can easely be explained by the fact that most of our controls and patients are presently, or were in the past, barefoot agricultural workers at least for a part of their life. Under this hot and humid tropical climate, skin-macerating conditions are frequently observed and favour recurrent streptococcal invasion of the skin and the lymphatics, amplifying the lymphedema-associated morbidity observed in lymphatic filariasis. Moreover a role for these streptococcal skin infections has recently been proposed for explaining the high level of rheumatoid arthritis observed in Polynesia. These data confirm the interest of rapidly initiating long-term antibiotic therapy, in ADL as for erysipela, in order to manage the progression of the disease process.

\section{ACKNOWLEDGEMENTS}

W e are grateful to Patrick Luquiaud (Laboratoire d'analyses médicales, Institut Malardé, Papeete) for his help in performing the ASLO assays, and to Dr Luc Nicolas (Institut Pasteur, Paris, France) for critical reading of the manuscript.

\section{REFERENCES}

AYouB E.M. Immune response to group A streptococcal infection. Pediatric Infectious Diseases, 1991, 10, 15-19.

Bradley D.J. Tropical diseases: the burden and its implications. Schweiz Medical Wochenschr, 1997, 127, 1592-1597.

Chanteau S., Moulia-Pelat J.P., Glaziou P., Nguyen L.N., Luquiaud P., Plichart C., Martin P.V.M. \& Cartel, J.L. Og4C3 circulating antigen, a marker of infection and adult worm burden in Wuchereria bancrofti filariasis. Journal of Infectious Diseases, 1994, 170, 247-250.

Chartier C. \& Grosshans E. Erysipelas. International Journal of Dermatology, 1990, 29, 459-467.

Fan P.C., PEng H.W. \& Chen C.C. Follow-up investigations on clinical manifestations after filariasis eradication by diethylcarbamazine medicated common salt on Kihmen islands, republic of China. Journal of Tropical Medicine and Hygiene, 1995, 98, 461-464.

Kaplan E.L.B., Anthony B.F., Chapman S.S., Ayoub E.M. \& WANNAMAKER W. The influence of the site of infection on the immune response to group A streptococci. Journal of Clinical Investigation, 1970, 49, 1405-1414.

Nguyen L.N., Plichart C. \& Esterre P. Assessment of immunochromatographic test for rapid lymphatic filariasis diagnosis. Parasite, 1999, 6, 355-358.

Nicolas L. New tools for diagnosis and monitoring of Wuchereria bancrofti parasitism: the Polynesian experience. Parasitology Today, 1997, 13, 370-375.

Nutman T.B. \& Weller P.F. Filariasis and related infections. In: Harrison's principles of internal medicine. Isselbacher, Martin et al. Eds., McGraw-Hill, New-York, 1994, p. 920-924. 
Olszewski W.L., Jamal S., Manokaran G., Lukomska B. \& KUBICKA U. Skin changes in filarial and non-filarial lymphoedema of the lower extremities. Tropical Medicine and Parasitology, 1993, 44, 40-44.

Olszewski W.L., Jamal S., Dworczynski A., Swoboda E., Pani S., Manokaran G., Kumaraswami V. \& Bryla P. Bacteriological studies of the skin, tissue fluid and lymph in filarial lymphedema. Lymphology, 1994, 27, 345-348.

Ottesen E., Duke B.O.L., Karam M. \& Behbehani K. Strategies and tools for the control/elimination of lymphatic filariasis. Bulletin of the World Health Organization, 1997, 75, 491-503.

PARTONO F. The spectrum of disease in lymphatic filariasis. In: Filariasis, Evered \& Clark Eds., Wiley, Chichester, UK, 1987, p. 15-31.

Schacher J.F. \& Sahyoun P.F. A chronological study of the histopathology of filarial disease in cats and dogs caused by Brugia pahangi (Buckley \& Edeson, 1956). Transactions of the Royal society of Tropical Medicine and Hygiene, 1967, 61, 234-243.

Shenoy R.K., Sandhya K., Suma T.K. \& Kumaraswami V. A preliminary study of filariasis-related acute adenolymphangitis with special reference to precipitating factors and treatment modalities. Southeast Asian Journal of Tropical Medicine and Public Health, 1995, 26, 301-305.

Suma T.K., Shenoy R.K., Varghese J., KuttikKal V.V. \& KumaRASWAMI V. Estimation of ASO titer as an indicator of streptococcal infection precipitating acute adenolymphangitis in brugian lymphatic filariasis. Southeast Asian Journal of Tropical Medicine and Public Health,1997, 28, 826-830.

Vincent A.L., Rojas C.A.U., Ayoub E.M., Ottesen E.A. \& HarDEN E.G. Filariasis and erysipela in Santo Domingo. Journal of Parasitology, 1998, 84, 557-561.

Reçu le 4 novembre 1999

Accepté le 31 mars 2000 